\title{
Custom Mat as A Local Wisdom of Whistleblowing Mechanism of Village Funds in East Sumba
}

\author{
Rammy Inkenny Immanuel Ndaparoka ${ }^{1}$, Intiyas Utami ${ }^{2}$ \\ \{232015518@student.uksw.edu'1, intiyas@staff.uksw.edu $\left.{ }^{2}\right\}$
}

Universitas Kristen Satya Wacana Salatiga, Indonesia ${ }^{1,2}$

\begin{abstract}
This study aims to determine the role of culture in the implementation of whistleblowing system in Kuta Village, East Sumba. This research is a qualitative research using interviews for data collection technique. The speakers in this study were village officials, custom chiefs, and village communities involved in managing village funds. Based on the results of interview analysis, it can be concluded that the local culture of Sumba namely "custom mat" is the local wisdom of whistleblowing mechanism and the philosophy of "Mbola Mapabolung, Lipit Mapakahang" encourages individuals to have high intention for whistleblowing. Village officials and the community have high desire to conduct whistleblowing because the customary values they adhere to encourage awareness that fraud and corruption are bad things and must be stopped.
\end{abstract}

Keywords: whistleblowing, village funds, local wisdom

\section{Introduction}

Fraud in Indonesia is ranked $89^{\text {th }}$ out of 180 countries internationally (Humas, 2019). Wells (2011) argues that fraud can occur because of the three conditions known as "fraud triangle" i.e. individual's opportunity, pressure, and rationality. Fraud is a wrong and irresponsible action by doing anything for personal gain and it results losses to others (Yulifah \& Irianto, 2014). Fraud includes a variety of irregularities and illegal actions which prelude the fraud. Situational pressure can trigger someone to commit fraud (Singleton \& Singleton, 2010). A situational pressure can be described as condition of financial difficulty experienced by a company or organization (Beasley, Hermanson, Carcello, \& Neal, 2010).

Fraud in Indonesia is also rampant in the management of village funds. Village funds should be used for improving the welfare of rural communities, improving public services for the even distribution of village development, improving the village economy, reducing the gap of inter-rural development, and strengthening village communities not as objects but as subjects in the development (Republic of Indonesia, 14b). The phenomenon shows that there is a lot of manipulation in the use of village funds in various regions in Indonesia. In 2018, there were 96 corruption cases related to village funds and 65 of them were carried out by the village heads (Primayogha, 2018). The most recent case occurred in the Kepuhanyar-Mojokerto area. Agung Priyanto as the head of Kepuhanyar Village allegedly committed corruption for the Kepuhanyar annual budget in 2016 amounted to Rp 690,922,390. Another fraud case occurred in Labuan Tangga, Riau which Jumadi as the village head in Labuhan Tangga of Bangko SubDistrict of Rohil Regency was implicated in a corruption case of village funds of Rp. 399 million from the Rohil village budget in 2015 (Budianto, 2018).

Agusyani, Sujana, \& Wahyuni (2016) explained that the effort to expose fraud can be done by opening whistleblowing channels. There are a lot of efforts of corruption uncovering by whistleblowers in Indonesia, especially in government agencies. The latest case was revealed by the former Minister of Energy and Mineral Resources (ESDM), Sudirman Said. Sudirman revealed the fact that the chairman of the House of Representatives (DPR) carried out unethical actions with a businessman from a large company. From various cases that occurred in Indonesia, not a few of reporters experienced ironic dilemmas and conditions. This has led to the re-issuance of the Witness and Victim Protection Act No.13/2006 (Nurhidayat, 2017). In Indonesia, the whistleblowing system that has been carried out by the 
government includes, among others, the Ministry of Finance that opens a website as a fraudulent reporting channel in the Ministry of Finance of the Republic of Indonesia (Kemenkeu, n.d.). A whistleblower is someone who exposes unethical actions and gives information about illegal activities in public or private organizations (Vandekerckhove \& Lewis, 2012).

Cases of village funds abuse occur in various places in Indonesia. Corruption cases in the use of village funds have also occurred in Sumba Island, especially in East Sumba. Some village heads have been arrested in connection with this abuse (Ropo, 2019). East Nusa Tenggara is a province in the eastern part of Indonesia which has 21 districts with a population of 5,456,203 in 2019. NTT Province consists of approximately 550 islands which the three main islands are Flores Island, Timor Island and Sumba Island. East Nusa Tenggara is placed at the third rank as the poorest province in Indonesia. This research will focus on Kuta Village, East Sumba district. Kuta Village is the focal point of coastal tourism development by the East Sumba Regional Government.

The Kuta village as one of the villages that has strong customs currently faces the misuse of village funds. Village funds should be received by village officials and managed for village development. Unfortunately, in fact, this has not been implemented properly. By custom law, the values of commitment have been upheld in Kuta village in carrying out government's duties. The existence of abuse cases in various villages, including in Kuta village the courage of individuals to do whistleblowing as one of factors to detect fraud has prompted initiation of this research.

Utami, Utami, \& Hapsari (2016) in their research on village financial management in Central Java explained that local wisdom has a pivotal role in disclosure of fraud. Some people still feel reluctant to report fraud because some of the perpetrators are also their relatives that may cause problem on the family relationship and as a result when a fraud or misuse of village funds occurs; it will be settled in a family manner without involving legal processes.

The purpose of this study is to explain the mechanism and philosophy of the local wisdom of the Sumba region that encourages individuals to do whistleblowing. This study is useful for the village government and the government of Waingapu City of East Sumba to gain deeper knowledge about the role and influence of East Sumba's local culture on individuals and communities in the desire to act whistleblowing. The results of this study are also expected to provide an introduction and implementation of a whistleblowing system for the village officials, government and community in East Sumba, especially in Kuta village. This study provides a theoretical contribution in explaining a whistleblowing mechanism in the context of fraud associated with local wisdom in a village.

\section{Literature Review \\ 2.1 Village Fund}

Based on Act No. 6 of 2014 concerning Villages, villages are given the authority to regulate and manage their own authority in accordance with their needs and priorities. Anwar (2012) said that village is a legal community unit that has the authority to manage and regulate the interests of the local community based on the origins and customs adopted in the national government system and located in the district. The village government is run by the village head or village apparatus as an element of village administration. In addition to the village apparatus, there is also a Village Consultative Body (BPD) which is an institution that carries out a government function whose members are representatives of the village community and based on regional representation and are chosen democratically (Nafidah \& Anisa, 2017).

The Home Ministerial Decree No. 113 of 2014 concerning Village Finance Management states that the management of village funds is based on transparent, accountable and participatory principles and is carried out orderly and in budgetary discipline. The village financial management includes several activities, namely: (1) Planning as the initial stage of management of village funds which it comprises activities and budgeting for 1 (one) budget year and in which at this stage the village head together with the community conduct musrembang (a village development planning meeting); (2) Implementation which in a form of budget realization and planning of activities that have been jointly arranged in the musrembang, which the implementation is carried out by the village community in self-management in accordance with the principles of activity implementation. (3) Administration which in carrying it out the village head can determine the treasurer whose job is to save, deposit, and to be accounted for the receipt and expenditure of village fund management and the determination is made before the fiscal year and all 
based on the decision of the village head. (4) Reporting that is carried out by the village head to the mayor or regent and that is also reported to the BPD, which the reporting of the use of village funds consists of first semester report for the end of July of the current year and the final semester report for the end of January of the following year. (5) Responsibility of village fund that is carried out by officials authorized to make accountability reports to the community in the form of accountability reports prepared in accordance with the village financial reporting standards. The period of management of village funds is one year budget from 1 January to 31 December of the current year.

\subsection{Fraud in Managing Village Funds}

Fraud according to Hall (2011) is an inappropriateness of material facts made by certain parties in order to deceive and harm other concerned parties. Fraud occurs because of the existence of three conditions called the "Fraud Triangle" i.e. there are opportunity, pressure and rationalization (Wells, 2011). In managing the village fund, the three conditions have great potential to occur. Considering this reason, the government and the community must be active in preventing the fraud of village funds and conflicts of interest. This can be realized by joint monitoring in the process of village development.

The regulation regarding village guarantees communities to actively participate in the monitoring and village development processes. Act No. 82 concerning the Village dictates that the general public has the right to obtain detailed information about village funds and the right to actively participate in monitoring the development process. Various evidence of frauds or indications of frauds that are found in the form of findings or complaints in the process of village development can be submitted to the village head or to the Village Consultative Body. Efforts to monitor the development of village management and village development are expected to increase the accountability of the village government. Monitoring of village funds can be carried out indirectly through organizations or institutions that are indirectly related to village management.

In the supervision of village funds, one sometimes does not have the courage to disclose fraud. In a study conducted by Taylor \& Curtis (2013), there are several aspects affecting this condition. First is the concern of retaliation from the reported parties. The risk of retaliation threat from the perpetrators who threaten reporters and their families causes a reluctance to report any frauds. Second, the lack of adequate support and facilities from organizations for whistleblowers can be another factor not to disclose any frauds.

\subsection{Whistleblowing}

Miceli \& Near (1985) state that whistleblowing is an act of disclosure by a member of an organization about illegal and/or immoral practices in the organization. Individuals who report fraud or carry out whistleblowing are referred to as whistleblowers. The whistleblowing action needs to get support from various parties so that it can run well. The whistleblowing in this study is the reporting action carried out by member(s) of an organization (active and non-active) regarding violations, frauds, as well as illegal, unethical and immoral actions to the village government or to the parties outside of the village government. Previous research by Widiyarta (2017) indicates that whistleblowing has a positive influence on prevention of fraud in managing village funds. There are many cases of whistleblowing which officers report their organizations they work for due to fraud or unethical activities. Sweeney (2008) also reveals that reports carried out by a whistleblower proved to be more effective in uncovering fraud compared to other methods such as internal control, internal audit, and external audit.

Factors causing fraud such as opportunity, pressure, and rationalization of greed are the reasons why a whistleblowing system is implemented in an organization. A whistleblowing system is used not only as a fraud reporting channel, but also as a form of supervision. Workers will be afraid to commit fraud because this system can be used for all workers, so that fellow workers will supervise each other. This will help in preventing potential fraud in the management of village funds.

It is necessary to understand the factors that can influence the intention of village officials to carry out whistleblowing actions so that organizations can design the most effective whistleblowing system. It is important for whistleblowers to participate in a whistleblowing system or this system will not be useful if no one uses it to report any fraud. Based on data issued by the Association of Certified Fraud Examiners Indonesia Chapter (2017) the best and most effective method of prevention of fraud is through 
a whistleblowing hotline mechanism than other methods such as on-site audits and external audits upon financial statements.

Elias (2008) stated that there are two types of whistleblowing, namely internal and external whistleblowing. Internal whistleblowing occurs when an officer discovers a fraud committed by other officers; he reports the fraud to the village head or to a higher government body. External whistleblowing occurs when an officer finds out about fraud committed by the office where he works then discloses it to the public for he consider that the fraud can harm the community. A person's decision to become a whistleblower can be influenced by individual variables or organizational contexts. Examples of individual variables are costs and benefits, age, marital status, and education. While, the organizational context includes cultural ethics, ethical climate, organizational size, organizational structure and communication channels.

Relativism is the rejection towards attitude of moral values that is directed to individual behavior. In this case, individuals still consider some values that come from within themselves as well as from their environment (Forsyth, 1980). Ethical relativism is a theory stating whether an action can be said to be ethical or not, right or wrong, depends on the community's perspective. If staffs or employees have high realism, they will tend not to conduct unethical behavior and they will assume that internal whistleblowing is an important action to avoid unethical attitudes and actions that can put an organization in danger position (Husniati, 2017). The study conducted by Yulianto (2015) found that an orientation towards ethical relativism influences government apparatuses to conduct internal whistleblowing.

Another factor that influence internal whistleblowing is moral intensity. Moral Intensity can be associated with the concept of perception of behavioral control in the theory of planned behavior. Research conducted by Kreshastuti \& Prastiwi (2014) found that moral intensity has a positive influence on internal whistleblowing. Organizational commitment also has an influence in internal whistleblowing. This research is supported by the results of study by Nurkholis (2015) which shows that organizational commitment affects civil servants' interest in conducting whistleblowing. A person who upholds professional identity will foster a character of compliance with the legal basis and rules of conduct. A sense of professionalism from someone will create a sense of responsibility towards the place where he works. When there is a violation of the applicable regulations, the intention to do a whistleblowing will come up (Husniati, 2017).

\subsection{Local Wisdom and Whistleblowing Mechanism}

Local wisdom is one of the external factors that influence a person's behavior (Maheswara \& Shavitt, 2000). The factor of local wisdom or local culture is one of the variables that influence the intention to do whistleblowing. Previous research by Tavakoli, Keenan, \& Crnjak-Karanovic (2003), MacNab, Galperin, \& Lituchy (2007), Park, Blenkisopp, \& Oktem (2008) and Hwang, Chen, \& Staley (2013) use Hofstede's cultural dimensions to compare cultures in two more countries that have different cultural dimensions.

Review of literature by Gao \& Brink (2017) focuses on determinants of the desire for whistleblowing including the characteristics of whistleblower, characteristics of the recipient of report, characteristics of the perpetrators of fraud and characteristics of the organization. The success of an effective whistleblowing is determined by the policies of an organization. In a hierarchical organization, there is no culture that shows freedom for employees to express their opinions, especially when there are differences of opinion. Organizations that do not take feedback and advice seriously indicate that they are not successful in implementing an effective whistleblowing policy (Teen, 2004).

Besides organizational culture, there is also a broader corporate culture and the culture of society that influence employees in the future. In some countries, cooperation in corporate community is very close and if they generally view whistleblowers negatively, whistleblowers not only will lose their job, but also they will suffer risk of losing other employment opportunities.

The opportunity for fraud and corruption by the village officials comes from the lack of a good control system and lack of reward system for each person. The local culture also plays an important role in helping or hindering the progress of whistleblowing system. In fact, sometimes individuals do not want to be whistleblowers because of their personal or cultural values. Unfortunately, whistleblowers are labeled as "bad things", referred to as traitors, and individuals who commit fraud are labeled as "family" 
or "friends". A culture that provides a room for individuals to express their opinions and an appreciation of their actions can prompt someone to become a whistleblower.

The whistleblowing mechanism can be in a form of an anonymous suggestion box, e-mail, website, telephone, or letter. A whistleblower may include his name when he reports or chooses to report anonymously. Reporting can be done to internal or external parties. Reports over suspected violations can be notified through a whistleblowing system, if according to the reporter, complaints through formal channels are ineffective or dubious.

\section{Research Method}

This study is a qualitative type study using in-depth interviews. This study was conducted in Kuta Village, Waingapu City of East Sumba of East Nusa Tenggara. Data collection was conducted in October 2018. Informants were stakeholders in the Village Fund consisting of elements from the village government, namely the Village Head and Village apparatus, community organizations (members of the Village Consultative Body), Customary Leaders, Non-Governmental Organizations, and journalists of village funds.

The results of the interviews were recorded and documented systematically. Information that has been obtained was then reviewed by combining and grouping information into a format that is appropriate and explained in more detail. The analysis technique was done by organizing data; sorting it into manageable units; finding pattern and what is important and what can be learned, then deciding what can be conveyed to readers. The process of data analysis begins by examining all available data from various sources; observations are written in field notes, personal documents, official documents, pictures, photographs and so on.

\section{Results And Discussion}

\subsection{General Description of Kuta village of Kanatang Subdistrict}

Administratively, Kuta village is one of the traditional villages located in the southern part of City of Waingapu, which on the north bordering with Hambapraing village, on the south bordering the Temu village, on the east bordering the sea, and the west bordering with Ndapayami village.

Kuta village has a population of 1,074 people consisting of 539 men and 535 women. This population occupies 16 RTs and 8 RWs with a size of $49.9 \mathrm{~km}^{2}$ (Waingapu City Central Bureau of Statistics).

Most of the population work as animal farmers, Sumba fabric farmers and weavers. Some also work in formal and informal sectors in the City of Waingapu or at the village hall. In Kuta village, groups of workers have been formed, including a cooperative with 50 members; a Combined Farmer Group with 40 members, a SPP Group with 20 Members, Village-Owned Enterprises (BUMDES) with 20 members and a Village Women Farmer Group with 56 Active members. In addition, in Kuta village, a group of female goat and cow farmers has been created.

Village fund was firstly given by the government for Kuta village in 2015. A number of people formed a work team and a support team as supervisors of activities related to village fund management. In 2018, Kuta village implemented pre-development plan meetings and development plan meetings. Each outcome of these meetings will cover 4 things, namely: 1) administration of government, 2) construction of facilities and infrastuctures, 3) community development, 4) empowerment. Those meetings involve various elements of the society including community institutions, community leaders, and village communities to jointly discuss and plan the types of activities that will be carried out by the village.

\subsection{Village Management Mechanism}

Planning is an activity carried out in the management of village funds; this phase includes planning and budgeting. Planning activities begin with the preparation of a Village Government Work Plan (Village RKP) which is a description of the Village Medium Term Development Plan (Village RPJM) for a period of 1 (one) year. In the RPJM and RKP, the village government organizes village meetings attended by the village government, the village council and the community. In village meetings, all things needed by each community will be conveyed and discussed, and they will determine the prioritized activities. 
The implementation phase is realization of all planned activities related to the management of village funds that have been agreed upon by the village government, Village Consultative Body (BPD) and elements in the community. In implementing the stipulated village budget, it creates transactions in the form of village receipts and expenditures, which all transactions are made through the village treasury account. All transactions must be supported by complete proofs and the implementers of activities must carry out each the mandatory activities must supply necessary documents, i.e. the Budget Plan verified by the village secretary and authorized by the Village head.

The Village Head appoints the Village Treasurer to conduct village finance management before the budget for the current year begins. His task is to receive, save, pay, deposit and administer and account for the management of village funds.

The treasurer of the village head reports in the form of a report on the realization of the use of village funds budget at each phase and the realization of the budget usage report for regent/mayor for 1 (one) budget year that must be calculated by the village head. All reports on the realization of the budget can be accessed by the community and are used as evidence of the use of village funds in carrying out activities.

The Village Act No. 82 states that the public and the community have the right to know and have all detailed information about village funds and actively participate in the development process. Planning transparency in Kuta village can be seen from invitations to all villagers and elements of the community and village government to jointly conduct pre-development plan meeting and development plan meeting. The following are the results of interviews with informants, namely Mr. KP and Mr. SH who showed transparency in the village fund planning management:

"Kuta village has 3 funding sources, namely the National Budget, the Regional Budget (village budget allocation and tax distribution) before the funds are disbursed at the beginning of the year, which the pre-development plan meeting will be held to accommodate all proposals from the institutional components of the community, namely schools and integrated health posts. In the development plan meeting of city government (Municipal Planning Agency, Waingapu City Empowerment Agency, the finance department and the city Inspectorate) were present to monitor the village development plan meeting directly"

"In 2018, we have held village development plan meetings in April and the realization also took place this year. So the village development plan meetings are always carried out involving government, religious leaders, youth leaders, environmental groups, PKK (family education) groups and other women's groups, which all are involved in giving opinions in the meeting."

From the results of the interview, it can be seen that transparency in planning has been done well, because the discussion on village development (musrembang) involves villagers to be able to participate in village development planning. Transparency and systematic planning to involve the concerned parties have been well planned. This is in accordance with the statement of Hanifah \& Praptoyo (2015) that deliberation in planning must be conducted openly for all stakeholders.

Planning for village fund management for 2018 in Kuta Village focuses more on education, community empowerment and assistance in the construction of 5 housing units. Every activity proposed in the musrembang (development plan meeting) must be in accordance with the medium-term village development plan (RPJM). Mr KP added:

"Yes, in the development discussion, we have proposed a budget for education and empowerment. Everything is done openly in the discussion, so that the people of Kuta village know the details of fund that is received and allocated".

Based on interviews, the carried out activities were in accordance with the needs of the village community so that this will enable the village vision and mission for the welfare of village community to be achieved. This is in accordance with the statement of Sumpeno (2011) saying that accountability in village governance involves the ability of village officials to be responsible for the carried out activities, which in this case is the development and village government.

The village development plan must be in accordance with the village priority scale based on the needs of the village community. Therefore, independence is an important factor in decision making which means free from the influence of certain parties, and this decision is agreed by the village head together with the village consultative body. The following is the result of interviews with several village officials about independence in the village fund planning: 


\begin{abstract}
"During the musrembang, the things that we propose are all stated in the RPJM. Most planned things have been realized well and evenly. However, problems still arise, namely the village fund for Kuta village always arrives late. In 2018, the village fund was received in August. The village fund is not given immediately for 50\% is given first and then the remaining $50 \%$ will be given in October."
\end{abstract}

The results of interviews indicate that village officials in decision making were not influenced by other parties. Planning has been done carefully and realization has been done well also, but the disbursement of village funds has not been given on time. This is in line with the statement of Agoes \& Ardana (2014) stating that the decision making by village officials must be free from influence or pressure from any party.

The Act of Village No. 3 of 2015 regulates the village assistance which aim to increase the capacity, effectiveness and accountability of village governments and village development. The Kuta village has an assistance team that serves to assist the village in implementing the program. Village facilitators must understand the village RPJM and also have the task of assisting the local government in coordinating village development planning and facilitating collaboration between villages and third parties related to village development. The following is the result of an interview with Mr. NM regarding the village assistance team to manage village funds:

"Every village has an assistant. Kuta Village has 3 (three) assistances. However, one of these assistants made an incorrect report about the use of village funds".

The interview above shows that the assistance team for Kuta village has not done a good job in assisting the village government in planning village funds. This is not in line with the statement of Susanti (2014) that the village assistance functions are to increase the capacity, effectiveness and accountability of the village government and village development.

Implementation is the most important part of an activity or program. In the Kuta village, a special team is assigned to carry out and manage activities funded by village funds. In this stage, the roles of various parties, both from the village government and the Kuta Village community are needed to participate in the implementation of village fund management. However, the obstacle in Kuta Village is the lack of quality of human resources to be included in village development, especially in infrastructure development. It can be seen that the village fund managers still use third parties for the physical development process without involving the village community. The following is the result of an interview with Mr. BP as a village official:

"All village funds are indeed used in full for all families who receive assistance from the village. All of them are divided into groups, such as the KWT (Farmer Women Group), Anggur Merah (people who receive village funds in the form of livestock such as horses, buffalos, cows and goats) and assistance in the form of seeds such as corn, rice and beans."

"However, in the infrastructure sector, it is the responsibility of village assistance who will manage it. For example, currently, a village monument inscription is being built which the village government gives money to the village assistant for that project. Another example is the stone fence which was built not by using village funds but from the local government".

The results of that interview explains that the use of village funds had been carried out and prioritized to meet community needs and improve the village welfare through empowering and developing village infrastructure. This finding is in line with the statement of Meutia \& Liliana (2017) that village funds are prioritized for the development and empowerment of rural communities.

Openness is needed by the Kuta village community regarding all the development processes that are being carried out. The implementing team implements it by putting up an information board containing the name of the activity, the amount of the budget and the schedule for carrying out physical activities. This information already exists in Kuta Village. The following is the result of an interview with Mr. RR:

"All funds and allocations that the village can and receive have been written on the board and MMT concerning details of the funds received that are placed in the village hall. By doing that, everyone may be able to know the details of the funds earned by the village".

Based on the results of the interview, the informant acknowledged that there had been direct control from the community and implementation of transparency phase had been provided by the activity management team. since the implementation of activity accompanied by a bulletin board, this is in line 
with the statement of Renyowijoyo (2013) that transparency is built on freedom in obtaining information relating to the public interest and can be directly obtained by those in need.

Village officials understand that the community service and village development are the things that must be done optimally and that community interests must be a priority. Therefore, village officials strongly decline if there are violations of regulations or misuse of village funds carried out by parties involved in the community service and village development. This is supported by interviews with Mr. KP:

"Providing the best for the Kuta village community has become a necessity for us. Providing maximum service for the community is by hearing their aspirations and their needs. It is the providing of the best service and assistance for schools, healthcare or businesses of the Kuta Village community. After the village community conveys all of aspirations, the village apparatus will accommodate and deliver it in the Musrembang".

The giving of services to the community and channeling aspirations of village community is the main concern for the village officials. All aspirations will be conveyed in the Musrembang. In terms of the accuracy and consistency of the Accountability Letter (SPJ) and realization of development, the government represented by the Regional Employee Agency (BKD) is supervised when the SPJ is completed. BKD is assigned to check the SPJ and the physical results of construction. This is in line with the results of an interview conducted with $\mathrm{Mr}$. SH:

"Village funds cannot be handled carelessly by us, because all of those funds are supervised, from the sub-district level and above. They will check whether we have SPJ and the actual results. If they are not in accordance with applicable standards, they are will certainly be questioned and investigated. If it turns out that there is an abuse in the use of funds, legal action must be taken.

Village apparatuses believe that the abuse of village funds is an awful act, for it will create a negative impact on the village community. The village head always urges village officials and communities who acknowledge of the abuse of village funds to immediately report them to the village head so that they can be followed up in a discussion forum with other village officials. This is in line with the statement of Rasul (2003) that any organization will require accountability to provide answers to community in general.

\subsection{Culture and Mechanism of Whistleblowing}

There are various risks emerging in handling village funds. The biggest risk is the opportunity to do fraud. Accuracy and transparency play an important role in this issue because they will help reducing opportunities to do fraud or reducing weaknesses in managing funds. Below is the result of an interview with one of the village officers named Mr. KP and Ms. YLW:

"All officials in the Kuta village office are native of Kuta village. This made all officials aware and care about village development, so that they cannot carelessly handle village funds. It is implemented by informing about funds that are received and used in detail to the village community".

Mr. Kp also added:

"Our village is a role model for other villages in East Sumba. Therefore, we strive to give our best to the village and the community. Errors were only misstatements or typos in the village financial statements. These errors were immediately corrected by us. The government level above us is always careful about all written income and expenses and in the form of tangible work".

From the result of the interview, it is concluded that village officials carefully handled village funds and understood the importance of funds for village development. This is in line with the statement of Huslina, Islahuddin, \& Syah (2015) and Agusyani et al. (2016) that the competencies possessed by human resources affect the prevention of fraud. However, fraud can be done not only by village officials but also by individuals who receive the village funds. This is supported by an interview with one of the villagers:

"Sometimes corruption is not only in the form of cash. There were some villagers who received village funds who did not use the funds properly. For example, some villagers received assistance in the form of corn and bean seeds. For example, if they are lazy, the seeds will be used as animal feed and thus, the provided fund will no longer be useful".

The result of the interview indicates that the opportunity to commit fraud not only owned by officials but also by those who accept it. This proves that in-depth knowledge about fraud is not owned 
by the village community and it is not in line with the statement Rahimah, Murni, \& Lysandra (2018) that individuals who have high moral level will be able to prevent fraud because the they will obey the rules in accordance with universally accepted ethical principles. Therefore, the village head and village officials always give advice and go directly to the community to observe the development.

The competency of village officials has a major influence in preventing fraud. The competency can be shown if the village officials have competency that in line with the needs of village management and carry out their duties properly in accordance with the applicable SOPs.

Fraud prevention can be done not only in terms of the competence of village officials, but also in the mechanism of whistleblowing. Unfortunately, the community is not ready to report fraud in Kuta village. It is shown from interviews with all village officials in Kuta village:

"For reporting tools in this village, nothing has yet been implemented. If something happens, usually residents will come directly to one of us, as village office workers. regarding the approach carried out by the village head and village officials only with meetings at the village hall “.

The result of the interview show that there was a good reporting mechanism and the community was given opportunity to make and carry out reports. However, the reporting system for indications of fraud is limited to reporting directly to officers. The whistleblowing mechanism has not been implemented in Kuta village. This is not in line with the statement of Titaheluw (2011) that whistleblowing is one of the methods used for prevention of fraud.

Village officials and the Kuta Village community have two ways to solve the fraud problem in management of Kuta village funds. First, "custom mat" is used to solve the fraud problem. The village officials and the community sit together on a "custom mat" which they sit on an original Sumba woven cloth that is used only at certain events. They then perform a "potong babi (pig slaughter)" ceremony with aims to make the perpetrator not to repeat the fraud and to give deterrent effect to him. Second, solution using legal channels if the perpetrator does not cooperate and the losses made by the perpetrator are material losses.

Culture is one of factors affecting a person to become a whistleblower. Sometimes, some people are afraid or hesitant to report frauds in the use of village fund. There are several reasons of this. First, people who commit fraud are their colleagues or families, so they only give a warning not to commit further fraud in the future. Second, it is because they don't want a bad family relationship caused by whistleblowing. Third, there is no support provided by the government to protect whistleblowers.

The local culture is one of determinants of someone's desire to do whistleblowing. The custom values for Sumba people influence them in carrying out whistleblowing. Sumba's philosophy is "Mbola Mapabolung, Lipit Mapakahang" which means the village communities although are diverse, they must remain in unity to build Kuta village to be better in the future. This value teaches people to be aware that acts of fraud in Kuta Village are bad things and must be stopped. It encourages people to do whistleblowing.

The people in Kuta village still have a strong sense of familiarity. However, it will not reduce the professionalism of the village officials. For officials, the world of work and personal relationship are two different things and they must be separated. This statement is supported by the result of an interview with Mr. KP as the village head:

"If there is fraud, we will report and investigate it immediately. This cannot be tolerated because it can disrupt the village development. If it is unchecked, surely, the villagers will no longer trust us as the village officials. Thus, the fraud must be handled fairly and transparently."

The officials will give a direct response when a fraud occurs to maintain the trust of the village community because they also realize the importance of public trust in the apparatus. This awareness must also be accompanied by maintaining village funds properly and giving courage to the villagers to disclose fraud. This can be realized by educating villagers regarding the management of village funds and the impact that they will get if the frauds occur and if the funds are not properly managed. This fact is in harmony with the statement of Auditya, Lucy, Husaini, \& Lismawati (2013) that the community must be given the opportunity to know about the honest and correct accountability.

Other factors that also influence a person's decision to become a whistleblower are individual variables such as cost \& benefit, education, age and marital status. These factors are triggered because consequences will arise when someone becomes a whistleblower. The community still has no courage to report fraud because of insufficient channels of reporting and lack of protection for the reporter/informant. 
The risk of retaliation is one of factors that reduce a willingness to report a fraud. This makes the reporter feels threatened and considers that reporting any frauds will not give benefits for him. In addition to the risk of retaliation, the reporter's action can also be hampered because there is an assumption that it is an unethical act.

Relativism is a rejection of moral principles in general because of the belief that there are no ethical standards that are absolutely true. This includes the role of professional organization as a guide for making of actions. Individuals who have low relativism tend not to do whistleblowing, because whistleblowing is seen as an unimportant thing. The desire to become a whistleblower is a personal factor, which refers to professional commitment. The higher of professional commitment, the higher of view that whistleblowing is important.

The Kuta village funds have been used to meet community needs related to community development, i.e. health, hygiene, education and community empowerment. The importance of the role of village funds for the community will encourage them to participate in supervising the use of funds so as not to hamper village development. Besides, it also encourages the community to report any potential problems and to participate directly in village development in order that the development can be completed on time. The village officials, especially village head, have responsibility to the national government to report the use of village funds. A sense of responsibility will prompt the village head to give mandates to village officials in making of accountability reports properly and correctly in accordance with the implementation of village development.

In running their government, village officials are required to provide their best efforts for the village community both in terms of community services and in the use of village funds. The village head requires his officials to prioritize community interests and minimize misuse of village funds. The village head is also responsible for giving approaches to the village officials to participate in monitoring of fund usage and to report any village fund abuses. The approach does not come only from the village officials, but also comes from the Inspectorate and advocates of Waingapu.

Village fund is the main source of village income so that its usage needs transparency from the communities and government who gives the authority to manage it. The village community's accountability is carried out through evaluation of village fund management led by the village head. In Kuta village, the village head conducts an evaluation together with his people related to the village fund management. This is shown by the results of an interview with Ms. YLW:

"Every time new funds come in, new received information will soon be socialized. For example, currently there are changes in the APBS and we will immediately publish it too."

Result of the interview indicates that the reporting of realization has been known to the Kuta Village community because the village manager has provided information about it, and it is in line with the statement of Mamuaya, Sabijono, \& Gamaliel (2017) that the village community must be informed about the accountability report.

The village officials work with traditional leaders and traditional villages in distributing funds and carrying out activities in Kuta village. Village funds that have been received are used to build villages and introduce woven fabrics and customs in Kuta village. The traditional leader does not directly involve in the planning of the Kuta Village Budget. This is shown by the result of an interview with a traditional leader:

"Regarding the amount of received funds, we knew it. However, we did not mix those money with all money from the village office. This is the work of the village officials who work at the village office".

From the result of the interview, it can be concluded that by excluding traditional leaders in village budgeting proves that local customs and traditional elders do not influence the village budgeting. This is in line with the statement of Widiyarta (2017) that the role of parties outside the village government, namely village leaders, religious leaders, traditional leaders must be involved in managing village funds rather than in village budgeting.

The sense of familiarity owned by the village officials and the community does not reduce the awareness and desire of individuals to report fraud. The growing individuals' awareness and courage is prompted by awareness about the adverse effects from the abuse of village funds, and as it results growing individuals' desire to do whistleblowing. Solving of fraud problem is done through village customs and in family manner without interference from the authorities or legal agencies. 


\section{Conclusion, Limitation and Recommendation}

\subsection{Conclusion}

This study aims to determine the role of culture in the implementation of a whistleblowing system in Kuta village of East Sumba. Based on the result of interview analyses, it can be concluded that the local culture of Sumba, namely "custom mat" and the philosophy of "Mbola Mapabolung, Lipit Mapakahang" influence individuals to do whistleblowing. The village officials and the community have enthusiasm to conduct whistleblowing because the custom values they adhere to encourage awareness that fraud and corruption are bad things and must be stopped.

\subsection{Limitation and Suggestion}

The limitation of this study is the limited number of speakers or informants who were only around the village, which are village officials as managers, the community and traditional leaders.

The suggestion for Desa Kuta is to maintain the values of local wisdom as a whistleblowing mechanism that supports village development. The results of this research are also useful for the related agencies who conduct guidance and supervision on the use of village funds. The future research can examine other cultural factors such as leadership in implementing village fund management.

\section{References}

[1]Agoes, S., \& Ardana, I. C. (2014). The challenge of building a whole person. Jakarta: Salemba Empat. [2]Agusyani, N. K. S., Sujana, E., \& Wahyuni, M. A. (2016). The influence of whistleblowing system and Human resources competence to fraud prevention. Jurnal Ilmiah Mahasiswa Akuntansi, 6(3), 1-10.

[3]Association of Certified Fraud Examiners Indonesia Chapter. (2017). Survay fraud Indonesia, 1-66.

[4]Auditya, Lucy, Husaini, \& Lismawati. (2013). Analysis of influence accountability and transparancy of regional financial management to the performance of local governments. Jurnal Fairness, 3(1).

[5]Beasley, M. S., Hermanson, D. R., Carcello, J. V, \& Neal, T. L. (2010). Fraudulent financial reporting 1998-2007, an analysis of U.S public company. New York: Committe of Sponsoring Organizations of the Treadway Commission.

[6]Budianto, E. E. (2018). Detik News. Retrieved February 26, 2018, from https://news.detik.com

[7]Elias, R. (2008). Auditing student professional commitment and anticipatory socialization and their relationship to whistleblowing. Managerial Auditing Journal, 23(3), 283-294.

[8]Forsyth, D. R. (1980). A taxonomy of ethical ideology. Journal of Personlaity and Social Psychology, 39(1), 175-184.

[9]Gao, L., \& Brink, A. G. (2017). Whistleblowing studies in accounting research: A review of experimental studies on the determinants of whistleblowing. Journal of Accounting Literature, 38(C), 113.

[10]Hanifah, \& Praptoyo. (2015). Accountability and transparancy of accountability of village expenditure budget (APBDes). Jurnal Ilmu \& Riset Akuntansi, 4(8).

[11]Humas. (2019). CPI Indonesia Naik 7 Peringkat Tahun 2018. Retrieved May 30, 2019, from https://www.kpk.go.id/id/berita/berita-kpk/739-cpi-indonesa-naik-7-peringkat-tahun-2018

[12]Huslina, H., Islahuddin, \& Syah, N. (2015). The influence of apparatus integrity, apparatus competence and Utilization of information technology to effectiveness fraud prevention system. Jurnal Administrasi Akuntansi, 4(2), 55-64.

[13]Husniati, S. (2017). Factors that influence intention to do internal whistleblowing. JOM Fekon, 4(1), 1223-1237.

[14]Hwang, D. B. K., Chen, Y., \& Staley, A. B. (2013). A comparative study of the propensity of whistle-blowing: empirical evidence from China, Taiwan, and the United States. Journal of Accounting and Financial Reporting, 3(2), 202-224.

[15]Kemenkeu. (n.d.). WiSe. Retrieved February 26, 2018, from https://www.wise.kemenkeu.go.id [16]Kreshastuti, D. K., \& Prastiwi, A. (2014). Analysis factors that affect intention of auditor to do whistleblowing (study in Kantor Akuntan Publik Semarang). Diponegoro Journal of Accounting.

[17]MacNab, B., Galperin, B. L., \& Lituchy, T. R. (2007). National homogeneity vs. regional specificity: an Eexamination of the Canadian cultural mosaic and whistle-blowing. Canadian Journal of Regional Science (Summer, 2007), 293-312.

[18]Mamuaya, J. V., Sabijono, H., \& Gamaliel, H. (2017). Analysis village financial management based 
Permendagri No. 113 year 2014 (Case study in Adow Village, Pinolosian Tengah Districts, South Bolaang Mongondow). Jurnal Riset Ekonomi, Manajemen, Bisnis Dan Akuntansi, 5(2), 1020-1030.

[19]Meutia, I., \& Liliana. (2017). Village fund financial management. Jurnal Akuntansi Multiparadigma, 336-352. https://doi.org/10.18202/jamal.2017.08.7058

[20]Miceli, M. P., \& Near, J. P. (1985). Characteristic of organization climate and perceived wongdoing associated with whistleblowing decision. Personal Psychology, 525-544.

[21]Nafidah, L. N., \& Anisa, N. (2017). Accountability of village financial management inKabupaten Jombang. Akuntabilitas, 10(2), 273-288. Retrieved from https://doi.org/10.15408/akt.v10i2.5936

[22]Nurhidayat, I. (2017). Bureaucrats write. Retrieved February 26, 2018, from http://birokratmenulis.org

[23]Park, H., Blenkisopp, J., \& Oktem, M. K. (2008). Cultural different forms of whistleblowing: A comparison of South Korea, Turkey and the UK. Journal of Business Ethics, 82(4), 929-939.

[24]Primayogha, E. (2018). Indonesia Corruption Watch. Retrieved February 26, 2018, from https://antikorupsi.org

[25]Rahimah, L. N., Murni, Y., \& Lysandra, S. (2018). The influence of presentation of village financial statements, control environment and individual morality toward fraud prevention that occured in the management of village fund allocations. Jurnal Ilmah Ilmu Ekonomi, 6(12), 139-154.

[26]Rasul, S. (2003). Integration of performance and budget accountability systems in perspective UU NO. 17/2003 about state finances. Perum Percetakan Negara, Republik Indonesia.

[27]Renyowijoyo, M. (2013). Public sector accounting non-profit organization (3rd ed.) (3rd ed.). Jakarta: Mitra Wacana Mulia.

[28]Ropo, R. (2019). Five village head in East Sumba was reported to the police regarding the management of village fund. Retrieved May 27, 2019, from http://kupang.tribunnews.com/2019/03/22/lima-kades-di-sumba-timur-dilaporkan-kepada-polisi-terkaitpengelolaan-dana-desa

[29]Singleton, T. W., \& Singleton, A. J. (2010). Fraud auditing and forensic accounting 4th ed. Wiley, United State of America: John Wiley \& Sons, Inc.

[30]Sumpeno. (2011). Integrated village planning (2nd ed.). Banda Aceh, Indonesia.

[31]Susanti, M. H. (2014). The role of village facilitators in encouraging community initiatives and participation towards independent village in Gonoharjo Village, Limbangan Districts, Kendal. Unnes, 94-104.

[32]Sweeney, P. (2008). Hotlines helpful for blowing the whistle, 24(4), 28-31.

[33]Tavakoli, A. A., Keenan, J. P., \& Crnjak-Karanovic, B. (2003). Culture and whistleblowing an empirical study of croatian and United States managers utilizing Hofstede's cultural dimension. Journal of Business Ethics, 43, 49-64.

[34]Taylor, Z. E., \& Curtis, M. B. (2013). Whistleblowing in audit firms: organizational response and power distance. Behavioral Research in Accounting, 25(2), 21-43.

[35]Utami, K. D., Utami, I., \& Hapsari, A. N. S. (2016). Whistleblowing village fund managements: a study of the vaue of local wisdom.

[36]Vandekerckhove, W., \& Lewis, D. (2012). The content of whistleblowing procedures: A critical review of recent official guidelines. Journal of Business Ethics, 108(2), 253-264.

[37]Wells, J. T. (2011). Corporate Fraud Handbook: Prevention and Detention (3rd ed.). Hoboken, New Jersey: John Wiley \& Sons, Inc.

[38]Widiyarta, K. dkk. (2017). Fraud prevention in village fund management ( Empirical study to the village government in Kabupaten. E-Journal S1 Ak Universitas Pendidikan Ganesha, 1.

[39]Yulianto, R. D. A. (2015). The influence of ethical orientation, of professional commitment, and athical sensivity to whistleblowing. Universitas Negeri Yogyakarta.

[40]Yulifah, A., \& Irianto, G. (2014). External auditor percetion about determination fraudulent financialstatements prevention. Retrieved February 26, 2018, from http://portalgaruda.org 